\title{
Physiological and pharmacokinetic responses in neotropical Piaractus mesopotamicus to the essential oil from Lippia sidoides (Verbenaceae) as an anesthetic
}

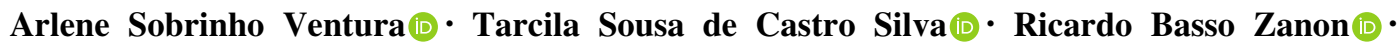 \\ Luis Antonio Kioshi Aoki Inoue 1 - Claudia Andrea Lima Cardoso $(\mathbb{C}$
}

Received: 31 October 2018/Accepted: 6 January 2019/Published online: 18 January 2019

(C) The Author(s) 2019

\begin{abstract}
The goal of the study was to evaluate Lippia sidoides essential oil as an anesthetic for the tropical fish pacu Piaractus mesopotamicus. The physiological and pharmacokinetic responses were evaluated during fish handling. Fish were exposed to different concentrations of the essential oil (20, 30, 40, 50, 60, and $70 \mathrm{mg} \mathrm{L}^{-1}$ ) to determine the induction times to anesthesia. The hematological parameters were determined in fish exposed to different concentrations of the essential oil $\left(20\right.$ and $\left.70 \mathrm{mg} \mathrm{L}^{-1}\right)$, which were enough to induce light and deep anesthesia in $10 \mathrm{~min}$. For pharmacokinetics purposes, blood samples were collected after exposure to the essential oil $\left(70 \mathrm{mg} \mathrm{L}^{-1}\right)$ for $10 \mathrm{~min}$ at different depuration times $(0,15$, and $30 \mathrm{~min}, 1,2,4$, 6, 8, 24, and $48 \mathrm{~h}$ ). Thymol was the major essential oil compound in Lippia sidoides, at $61.12 \%$. All physiological parameters returned to control values in $24 \mathrm{~h}$. Distribution and elimination of the major compound in the blood plasma were fast, being $64.31 \%$ in $1 \mathrm{~h}$. The distribution constant of the essential oil was $7.59 \mu \mathrm{g} \mathrm{h}^{-1}(\mathrm{k})$ in the organism. Therefore, when the plasmatic concentration of thymol was reduced, this constant decreased to $0.44 \mu \mathrm{g} \mathrm{h}{ }^{-1}(\mathrm{k})$. The AUC value was $38.05 \mu \mathrm{g} \mathrm{h}^{-1}$, the initial half-life during the distribution stage $\left(T_{1 / 2} \alpha\right)$ was $0.09 \mathrm{~h}$ and the elimination half-life $\left(T_{1 / 2} \beta\right)$ was $1.59 \mathrm{~h}$. Fish survival was $100 \%$ even 20 days after the experiments. Therefore, Lippia sidoides essential oil may be considered a safe anesthetic for tropical fish.
\end{abstract}

Keywords Fish $\cdot$ Handling $\cdot$ Hematology $\cdot$ Thymol

\section{Introduction}

Lippia sidoides Cham. 1832, folk name "alecrim-pimenta," is a medicinal plant, typical in the semi-arid "caatinga" region from northeast Brazil (Veras et al. 2014). Anaesthetic and antiparasitic properties of the $L$. sidoides essential oil are reported in fish, such as tilapia (Hashimoto et al. 2016) and tambaqui Colossoma macropomum (Soares et al. 2017). However, some side effects have been reported in R. quelen after anesthesia

A. S. Ventura $(\bowtie)$. C. A. L. Cardoso

Natural Resources Studies Center, State University of Mato Grosso do Sul, Highway Itahum Km 12, s/n, Dourados, MS,

Brazil

e-mail: arlenesventura@gmail.com

T. S. de Castro Silva - L. A. K. A. Inoue

Embrapa Western Agriculture, Dourados, MS, Brazil

R. B. Zanon

Environmental and Biological Sciences Faculty, Federal University of Grande Dourados, Dourados, MS, Brazil 
with the essential oil of $L$. sidoides, including mucous loss and mortality (Silva et al. 2013). Essential oil characteristics may induce different pharmacological and physiological responses in fish at distinguished intensity and profiles.

The use of essential oils from medicinal plants as anesthetics for fishes seems to be a feasible and safe alternative for both fishes and the environment (Guénette et al. 2007). Some natural compounds were related to fish anesthetic actions, such as eugenol, which is extracted from Eugenia caryophyllata (Guénette et al. 2007), menthol, obtained from Mentha piperita (Façanha and Gomes 2005), and the essential oils from L. alba (Cunha et al. 2010, 2011), Melaleuca alternifolia (Hajek 2011), and Ocimum gratissimum (Silva et al. 2012, 2015). Nevertheless, essential oils require additional study as fish anesthetics. In addition, pharmacological responses of fishes to essential oils as anesthetics are even scarcer.

In commercial aquaculture operations, fish are usually subjected to handling, and anesthetics are used to preserve their welfare during activities, such as biometrics, hormonal pellet implants, blood sampling, and injections (Inoue et al. 2003). Nevertheless, fish intended for human consumption that have been previously anesthetized with chemicals, such as tricaine methanesulfonate, need to undergo a clearance period of 21 days (Zahl et al. 2012). Thus, risks of fish once anesthetized escaping and being unduly consumed are substantial. These restrictions foster the need for more studies searching for natural fish anesthetics. The goal of this study was to evaluate the essential oil of $L$. sidoides as an anesthetic for use in the tropical fish pacu $P$. mesopotamicus, an experimental model.

\section{Material and methods}

Plant material

The L. sidoides plants were cultivated in an experimental field of the Embrapa Western Amazon in Manaus, Brazil $\left(2^{\circ} 53^{\prime} 35.73^{\prime \prime} \mathrm{S} ; 59^{\circ} 58^{\prime} 23.36^{\prime \prime} \mathrm{E}\right)$. The aerial parts of were cut and air-dried. The voucher specimen was deposited at the Embrapa Eastern Amazon herbarium under registration no. 002/2008, process 02,001.002726/ 2013-25. The essential oil was obtained by hydrodistillation, using a Clevenger-type apparatus (European Pharmacopoeia 2007). Essential oil yield was 1.0\% (mass/volume) based on air-dried aerial parts.

Fish

Pacu juveniles were purchased from a commercial fish hatchery in Dourados, Mato Grosso do Sul, Brazil $\left(22^{\circ} 06^{\prime} 49.57^{\prime \prime} \mathrm{S} ; 54^{\circ} 34^{\prime} 41.99^{\prime \prime} \mathrm{E}\right)$. Fish were transported in plastic bags and stocked in $1000 \mathrm{~L}$ fiberglass tanks for 30 days at Embrapa Western Agriculture facilities. Fish were fed twice a day, near to satiation with commercial pellets (32\% crude protein). Water supply was in a recirculating aquaculture system, and water quality parameters were kept at the species requirements. Temperature $\left(25.6 \pm 0.8^{\circ} \mathrm{C}\right)$, oxygen dissolved $\left(5.56 \pm 0.07 \mathrm{mg} \mathrm{L}^{-1}\right)$, water conductivity $\left(72.3 \pm 4.5 \mu \mathrm{S} \mathrm{cm}{ }^{-1}\right)$, and $\mathrm{pH}$ (7.0) were monitored daily. Feeding was suspended $24 \mathrm{~h}$ before the experiments. This study was developed accordingly to the ethics committee UEMS no. 006/2015.

Induction times in anesthesia experiment

To evaluate the anesthetic activity of the essential oil, pacu juveniles $(n=54)(119.30 \pm 20.17 \mathrm{~g}$ and $18.12 \pm 1.03 \mathrm{~cm})$ were individually transferred to three aquariums $(25 \mathrm{~cm}$ length $\times 20 \mathrm{~cm}$ width $\times 25 \mathrm{~cm}$ height) containing $8 \mathrm{~L}$ of water and the respective essential oil concentration to be tested. The essential oils were poorly soluble in water, they were initially dissolved in $95 \%$ ethanol at a 1:10 ratio (essential oil: ethanol). Anaesthetic solutions of $L$. sidoides EO were prepared a few minutes before the experiment. Treatment doses were based on a preliminary experiment, which was conducted to determine the lowest effective anesthetic concentration, based on the ideal anesthetic criteria (Marking and Meyer 1985). Fish were considered anesthetized when they completely lost equilibrium and were totally unable to regain an upright position, stage 3 of anesthesia (Woody et al. 2002). 
An initial pretest was performed to define the minimum anesthetic dose. Based on this test the tested concentrations for induction times to anesthesia were $20,30,40,50,60$, and $70 \mathrm{mg} \mathrm{L}^{-1}$. The experimental design was completely randomized with six treatments (concentrations) and three replicates (aquarium). Three fish were individually anesthetized in each aquarium $(n=3)$. Tests were conducted in sequence, from lowest to highest concentrations, with complete water change after each concentration test. The time that fish took to achieve the study anesthesia stage (described above) was registered in seconds. After this procedure, each fish was measured for field work simulation, and transferred in groups to recirculating aquaculture system (RAS) tanks and remained under observation for 20 days.

Fish physiological responses to anesthesia experiment

Pacu juveniles $(n=72)(110.5 \pm 25.9 \mathrm{~g}$ and $17.2 \pm 1.5 \mathrm{~cm})$ were randomly distributed in 12 holding tanks (volume $1000 \mathrm{~L}, 20$ fish per tank), within a recirculation aquaculture system. A completely randomized experimental design was set with four treatments and three replicates $(n=12)$. The control group was not submitted to any stress. Bath group without anesthetic and bath groups with anesthetic $\left(20 \mathrm{or} 70 \mathrm{mg} \mathrm{L}^{-1}\right.$ of the essential oil) were submitted to handling, characterized by the transference of fish from the respective holding tank to $20 \mathrm{~L}$ buckets. After this, fish were returned to the respective holding tank. The concentrations (20 and $70 \mathrm{mg} \mathrm{L}^{-1}$ ) were determined based on the previous experiment. Baths took $10 \mathrm{~min}$. Blood samplings were done in three different fish per replicate $(n=3)$ at time zero and $24 \mathrm{~h}$ after the anesthetic baths. Exposure for 10 min usually exceeded the induction time for individual fish, because of the fact that handling procedures often involve anesthesia of a large number of fish. The parameters of water quality were kept within the ideal conditions for the species.

Procedures for blood parameters analysis

Blood was sampled by puncture of the caudal vein with $3 \mathrm{~mL}$ syringes $(25 \times 0.7 \mathrm{~mm})$ containing ethylenediaminetetraacetic acid (EDTA 10\%). Samples were divided into two rates. The first was used to determine red blood cells (RBC) in a Neubauer chamber, hematocrit, by means of a micro-hematocrit method (Ranzani-Paiva et al. 2013), and hemoglobin concentrations, using the cyanmethemoglobin method (Drabkin 1948). These data were used to calculate the Wintrobe hematimetric indexes: mean corpuscular volume (MCV) and mean corpuscular hemoglobin concentration (MCHC) (Ranzani-Paiva et al. 2013). The second aliquot was centrifuged at $14,400 \mathrm{~g}$ for $3 \mathrm{~min}$ for plasma collection, to analyze glucose, protein, enzymatic lactate, and chloride using commercial kits (Labtest ${ }^{\circledR}$ Minas Gerais, Brazil), where as ammonia was determined according to Gentzkow and Mazen (1942). Regarding plasma sodium $\left(\mathrm{Na}^{+}\right)$and potassium $\left(\mathrm{K}^{+}\right)$, their determinations were made by flame photometry (910-M Marca Analyser).

Pharmacokinetic parameters

Fish $(n=30)$ were exposed to a $70 \mathrm{mg} \mathrm{L}^{-1}$ Lippia sidoides solution for $10 \mathrm{~min}$. This concentration was chosen based on the previous experiments. The bath was completed in $20 \mathrm{~L}$ of the anesthetic solution. The calculated concentration of the major component thymol was $43 \mathrm{mg} \mathrm{L}^{-1}$. After this period, the animals were transferred to $40 \mathrm{~L}$ glass aquariums (three fish per aquarium), $40 \mathrm{~cm}$ length $\times 30 \mathrm{~cm}$ width $\times 30 \mathrm{~cm}$ height, containing anesthetic-free water, continuous aeration, and open water supply. The parameters of water quality were kept within the ideal conditions for the species. Blood samples were collected from three fish at each time after the anesthetic bath $(0,15$, and $30 \mathrm{~min}, 1,2,4,6,8$, and $48 \mathrm{~h})$. Fish were properly discarded from the experimental facilities. Blood samples were collected with the aid of $3 \mathrm{~mL}$ syringes containing EDTA 10\%, centrifuged at $14.400 \mathrm{~g}$ for $3 \mathrm{~min}$ for plasma collection, which was stored in sterile flasks to be prepared and analyzed by gas chromatography-mass spectrometry (GC-MS).

Sample preparation for GC-MS analyses

For pharmacokinetic evaluation, $500 \mu \mathrm{L}$ of plasma was blended with $500 \mu \mathrm{L}$ of chromatographic degree hexane. The sample was homogenized and agitated in an ultrasonic tub with a timer for $1 \mathrm{~min}$, and later, the 
hexane fraction was analyzed by GC-MS; the test was performed in triplicate. For analytical curve construction, thymol was applied at different concentrations: $0.187,0.373,7.46,14.92,149.21,746$, and $1492 \mu \mathrm{g} \mathrm{mL}^{-1}$. Thymol was used because it is the main compound in the essential oil of L. sidoides.

GC-MS analysis

Analyses were performed in a gas chromatograph coupled to a with a mass spectrometer (GC-MS2010 Ultra), using DB-5 (30 m length $\times 0.25 \mathrm{~mm}$ internal diameter and film thickness of $0.25 \mu \mathrm{m}$ ) under the following

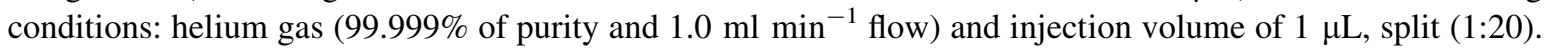
The initial temperature of the oven was $50{ }^{\circ} \mathrm{C}$ and it was heated from 50 to $280{ }^{\circ} \mathrm{C}$ at $3{ }^{\circ} \mathrm{C} \mathrm{min}{ }^{-1}$. The injector temperature was $220^{\circ} \mathrm{C}$ and both transfer line and detector temperatures were at $280{ }^{\circ} \mathrm{C}$. The retention index was calculated using a blend of linear alkanes $\left(\mathrm{C}_{8}-\mathrm{C}_{30}\right)$ as the external reference. Identifications were made by comparing the samples mass spectrums with that obtained from the libraries NIST21 and WILEY229, data from retention index and mass spectrum literature (Adams 2007).

Statistical analysis

All data were verified as following the necessary conditions before being subjected to variance analysis (oneway ANOVA; $\alpha=0.05$ ), including normality, variance homogeneity, and the presence of outliers. When significant differences were obtained, the Tukey test was applied to compare means of hour zero $(0 \mathrm{~h})$ after experimental procedures and $24 \mathrm{~h}$ recovery. The relationship between the essential oil concentration and anesthesia induction time was calculated by linear regression analysis. These tests were performed using SAS software. The essential oil concentrations in the plasma, in relation to depuration time, were analyzed with Graph Pad Prism 6.07 (Graph Pad Software Inc.; San Diego, CA, EUA). The elimination speed constant $(K)$, half-life $\left(T_{1 / 2}\right)$, and total area under the curve (AUC) were determined according to Jambhekar and Breen (2009).

\section{Results}

Chemical characterization of the essential oil

The quantitative and qualitative analysis showed the $L$. sidoides essential oil chemotype thymol as the major compound, $61.12 \%$, followed by o-cymene (11.64\%). It was determined that there were 29 compounds, representing $99.92 \%$ of the relative amount of crude oil (Table 1).

Anesthetic induction

Regarding the anesthetic aspects of the essential oil of L. sidoides, it was observed that all tested concentrations induced fish anesthesia. At first contact, fish became hyperactive, evidenced by fast swimming and opercular movements, which were reduced as the anesthetic effect was initiated. A decreasing linear effect was observed, i.e., as the anesthetic concentration increased, induction time to anesthesia decreased (Fig. 1).

The concentration of $70 \mathrm{mg} \mathrm{L}^{-1}$ enabled fish to rapidly achieve the anesthesia stage. Fish were anesthetized in less than $3 \mathrm{~min}$ in concentrations ranging from 30 to $60 \mathrm{mg} \mathrm{L}^{-1}$. Both fish weight $(\mathrm{g})$ and length $(\mathrm{cm})$ were easily measured, suggesting that the studied anesthesia stage was sufficient for routine procedures such as biometrics. All the fish recovered from anesthesia in approximately $1 \mathrm{~min}$. Differences were not significant. Concentrations between 20 and $70 \mathrm{mg} \mathrm{L}^{-1}$ of L. sidoides essential oil were efficient in anesthetizing P. mesopotamicus, without causing mortality.

Physiological parameters

Regarding the erythrocyte series, hemoglobin MCV and MCHC did not differ at zero and $24 \mathrm{~h}$ after the anesthetic baths. Twenty-four hours after anesthetic induction, hematocrit values of fish exposed to anesthesia 
Table 1 Chemical characterization of Lippia sidoides essential oil compounds

\begin{tabular}{|c|c|c|c|c|}
\hline Retention time (min) & IK calculated & IK literature ${ }^{a}$ & Components & Relative (\%) \\
\hline 7.32 & 925 & 924 & $\alpha$-Tujeno & 1.10 \\
\hline 7.56 & 932 & 932 & $\alpha$-Pinene & 0.42 \\
\hline 9.59 & 990 & 988 & Myrcene & 1.92 \\
\hline 10.11 & 1004 & 1002 & $\alpha$-Felandrene & 0.14 \\
\hline 10.35 & 1010 & 1008 & $\delta$-Carene & 0.19 \\
\hline 10.60 & 1018 & 1018 & $\alpha$-Terpinene & 1.61 \\
\hline 10.95 & 1024 & 1022 & 0-Cymene & 11.64 \\
\hline 11.10 & 1028 & 1024 & Limonene & 0.72 \\
\hline 11.20 & 1030 & 1026 & 1,8-Cineol & 0.55 \\
\hline 11.46 & 1036 & 1032 & Z- $\beta$-Ocimene & 0.12 \\
\hline 11.89 & 1046 & 1044 & E- $\beta$-Ocimene & 0.18 \\
\hline 12.36 & 1058 & 1054 & $\mathrm{y}$-Terpinene & 4.70 \\
\hline 13.62 & 1088 & 1086 & Terpinolene & 0.25 \\
\hline 14.10 & 1099 & 1095 & Linalool & 0.19 \\
\hline 16.28 & 1146 & 1140 & Ipsdienol & 0.36 \\
\hline 17.59 & 1178 & 1174 & Terpinen-4-ol & 1.81 \\
\hline 18.30 & 1193 & 1186 & $\alpha$-Terpineol & 0.17 \\
\hline 20.17 & 1235 & 1232 & Thymol metil ether & 1.53 \\
\hline 23.04 & 1300 & 1289 & Thymol & 61.12 \\
\hline 23.25 & 1301 & 1298 & Carvacrol & 0.36 \\
\hline 25.58 & 1359 & 1356 & Eugenol & 0.15 \\
\hline 26.35 & 1377 & 1374 & $\alpha$-Copaene & 0.66 \\
\hline 28.23 & 1422 & 1417 & E -Cariofillene & 6.39 \\
\hline 28.83 & 1437 & 1410 & $\alpha$-Cedrene & 0.15 \\
\hline 28.97 & 1441 & 1439 & Aromadendrene & 0.64 \\
\hline 29.60 & 1455 & 1452 & $\alpha$-Humulene & 0.44 \\
\hline 31.30 & 1497 & 1500 & $\alpha$-Muurolene & 0.56 \\
\hline 31.79 & 1509 & 1505 & $\beta$-Bisabolene & 0.25 \\
\hline 32.42 & 1525 & 1522 & $\delta$-Cadinene & 0.5 \\
\hline Total identified & - & - & - & 99.92 \\
\hline
\end{tabular}

$\mathrm{IK}^{\mathrm{a}}=$ Kovats retention index

${ }^{\mathrm{a} A d a m s}$ (2007)

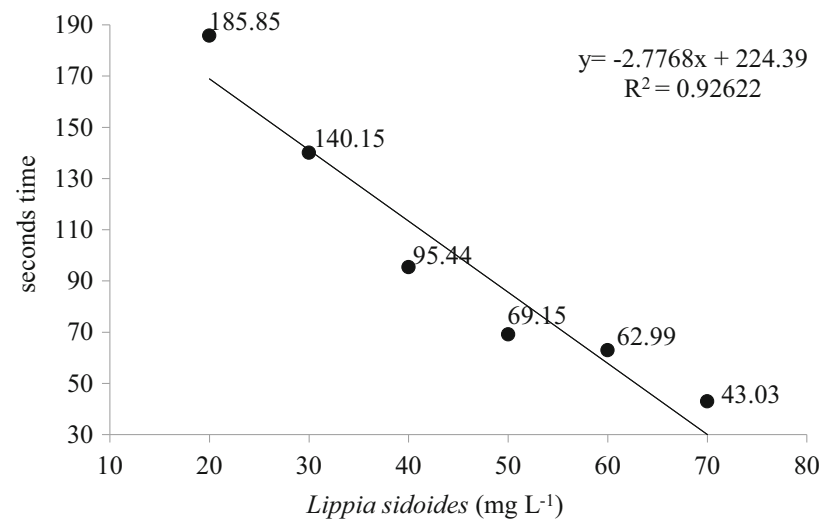

Fig. 1 Times (in seconds) to achieve anesthesia (complete loss of equilibrium and inability to regain the upright position) in Piaractus mesopotamicus exposed to Lippia sidoides essential oil as anesthetic. Equation: $Y=-2.7768 x+224.39 ; R^{2}=0.9262$ 
with $70 \mathrm{mg} \mathrm{L}^{-1}$ was elevated compared to that of the control but were similar to those exposed to the bath without the essential oil (Fig. 2). Total plasmatic protein was altered in fish exposed to baths containing $70 \mathrm{mg} \mathrm{L}^{-1}$ of the essential oil, differing from that of the control, but not from the handled and not anesthetized fish (Fig. 3).

Lactate values found in the control group were lower compared to that of the other treatments of fish both submitted to handling and anesthetics in concentrations of 20 and $70 \mathrm{mg} \mathrm{L}^{-1}$ (Fig. 3). This variable returned to the homeostatic values $24 \mathrm{~h}$ after the experimental procedures. Regarding plasma ammonia, no alterations were observed at any sampled time (Fig. 4). Fish exposed to 20 and $70 \mathrm{mg} \mathrm{L}^{-1}$ anesthetic baths presented plasmatic hyperglycemia compared to that of the control and handling groups at time zero. After $24 \mathrm{~h}$ recovery, only the fish exposed to $70 \mathrm{mg} \mathrm{L}^{-1}$ had glucose values altered in relation to that of the control group (Fig. 3).

Plasma $\mathrm{Na}^{+}$of fish exposed to the anesthetic did not differ from that of the control. As for $\mathrm{K}^{+}$, animals that were induced to anesthesia with the concentration of 20 and $70 \mathrm{mg} \mathrm{L}^{-1}$ presented an increased serum level of this ion. The ion $\mathrm{Cl}^{-}$in anesthetized fish with the concentration of $70 \mathrm{mg} \mathrm{L}^{-1}$ also was increased when
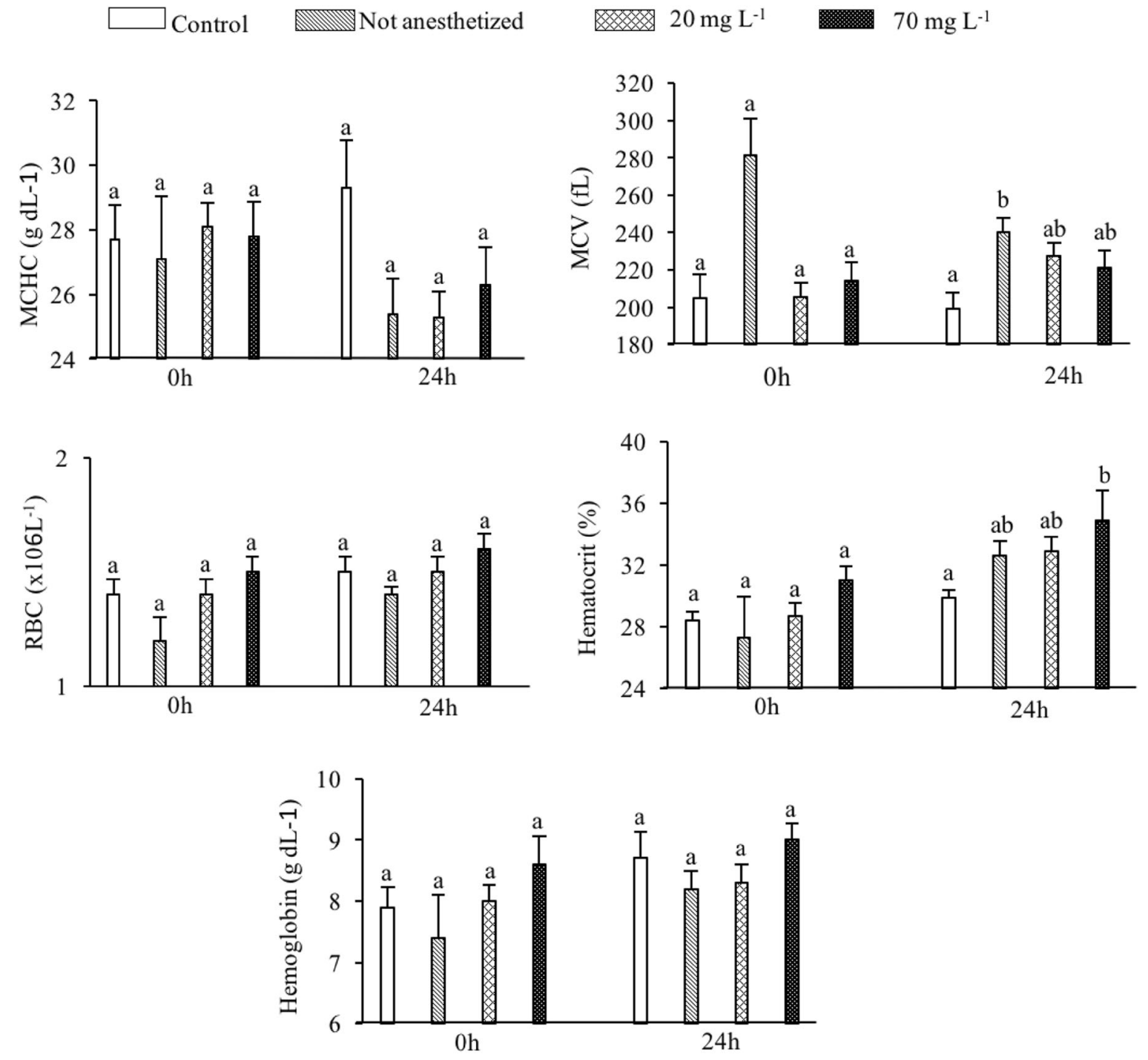

Fig. 2 Blood parameters of pacu subjected to anesthesia with essential oil Lippia sidoides. Blood samples were taken 0 and $24 \mathrm{~h}$ after the experimental procedures. Control—neither submitted to handling nor anesthetic. Values are means \pm standard error $(N=9)$, and different lowercase letters indicate significant differences between treatments within the same sampling time $(0 \mathrm{~h}$ or $24 \mathrm{~h})$, using ANOVA one-way and Tukey's test $(P<0.05)$ 


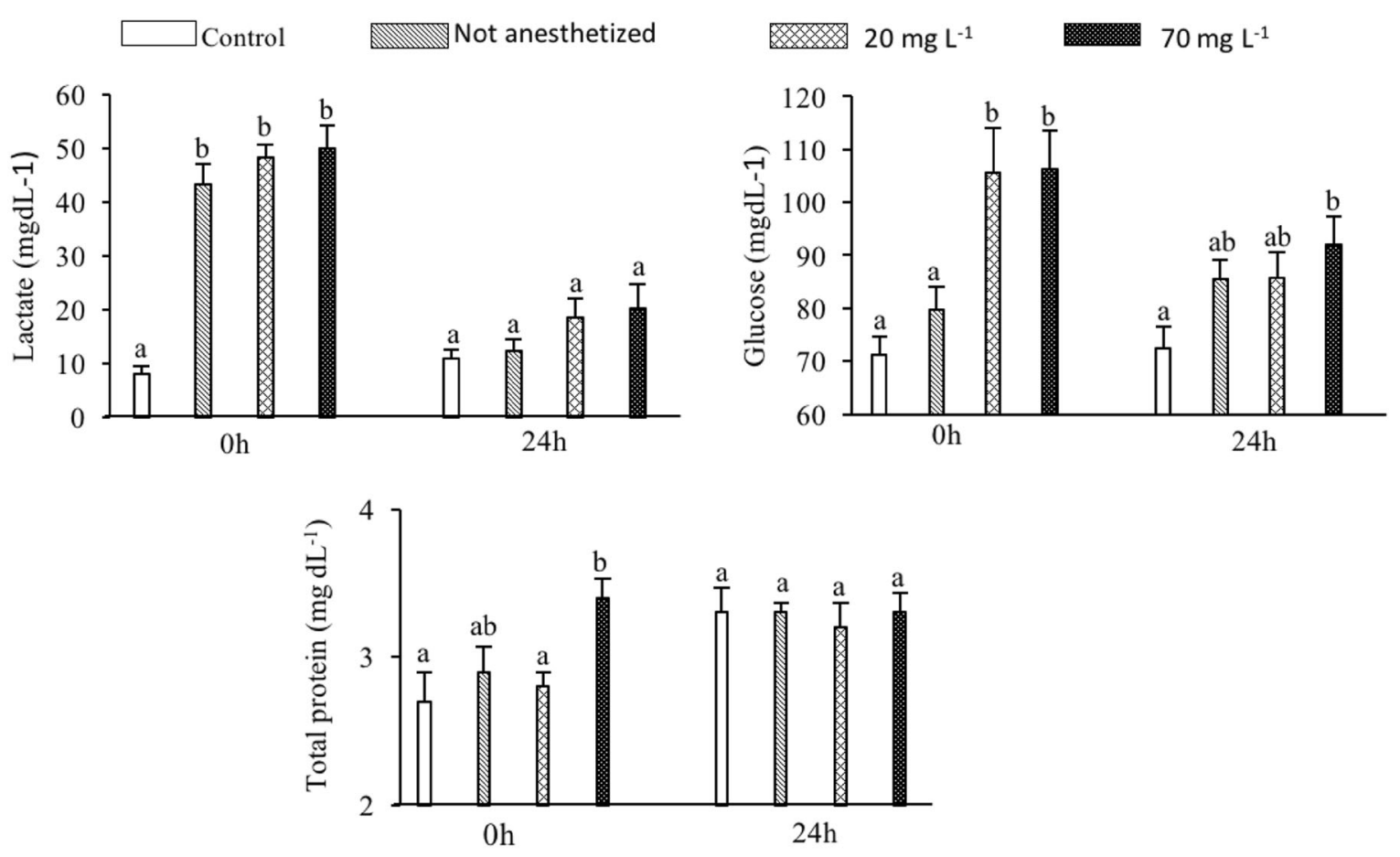

Fig. 3 Plasma levels of pacu subjected to anesthesia with Lippia sidoides essential oil. Blood samples were taken 0 and $24 \mathrm{~h}$ after the experimental procedures. Control—neither submitted to handling nor anesthetic. Values are means \pm standard error $(N=9)$, and different lowercase letters indicate significant differences between treatments within the same sampling time $(0 \mathrm{~h}$ or $24 \mathrm{~h})$, using ANOVA one-way and Tukey's test $(P<0.05)$

assessed immediately after the 10 min anesthetic bath at time zero (Fig. 4). After $24 \mathrm{~h}$ of anesthetic procedures, $\mathrm{Cl}^{-}$ions in fish anesthetized with $20 \mathrm{mg} \mathrm{L}^{-1}$ differed from that of the control group. $\mathrm{K}^{+}$ions increased in fish anesthetized with $70 \mathrm{mg} \mathrm{L}{ }^{-1}$ compared to that of the control group. $\mathrm{Cl}^{-}$ions increased in fish anesthetized with 20 and $70 \mathrm{mg} \mathrm{L}^{-1}$ (Fig. 4).

Pharmacokinetic Parameters

The pharmacokinetics of the main compound of the essential oil of L. sidoides, thymol on blood plasma of pacu was better described by the open model of two compartments with the elimination of the first order (Fig. 5). The maximum concentration of thymol within the blood plasma was $16.66 \pm 1.38 \mu \mathrm{g} \mathrm{ml}^{-1}$ immediately after anesthetic induction $(t=0)$. At the first depuration hour, a reduction of $64.31 \%$ of plasmatic thymol occurred, which continued to decrease for the following $8 \mathrm{~h}$. Six hours after exposure to the anesthetic agent, $1.03 \mu \mathrm{g} \mathrm{ml}^{-1}(6.18 \%)$ of the compound was found in plasma, representing a $93.82 \%$ reduction. After $48 \mathrm{~h}$, the plasmatic concentration of thymol remained constant at $0.4 \mu \mathrm{g} \mathrm{ml}^{-1}$, corresponding to the $2.46 \%$ of the initial concentration, thus, representing a total reduction of $97.54 \%$ of plasmatic thymol in the fish plasma (Fig. 5).

The distribution constant of the essential oil was $7.59 \mu \mathrm{g} \mathrm{h}^{-1}(\mathrm{k})$ in the organism. Therefore, when the plasmatic concentration of thymol was reduced, this constant was decreased to $0.44 \mu \mathrm{g} \mathrm{h}^{-1}(\mathrm{k})$. The AUC value was $38.05 \mu \mathrm{g} \mathrm{h}^{-1}$, the initial half-life during the distribution stage $\left(T_{1 / 2} \alpha\right)$ was $0.09 \mathrm{~h}$ and the elimination half-life $\left(T_{1 / 2} \beta\right) 1.59 \mathrm{~h}$ (Table 2 ).

\section{Discussion}

Several studies have reported thymol, a phenolic monoterpene, as the major compound of the L. sidoides essential oil (Monteiro et al. 2007; Oliveira et al. 2009; Cavalcanti et al. 2010; Medeiros et al. 2011; Veras 
$\square$ Control $\quad$ Not anesthetized
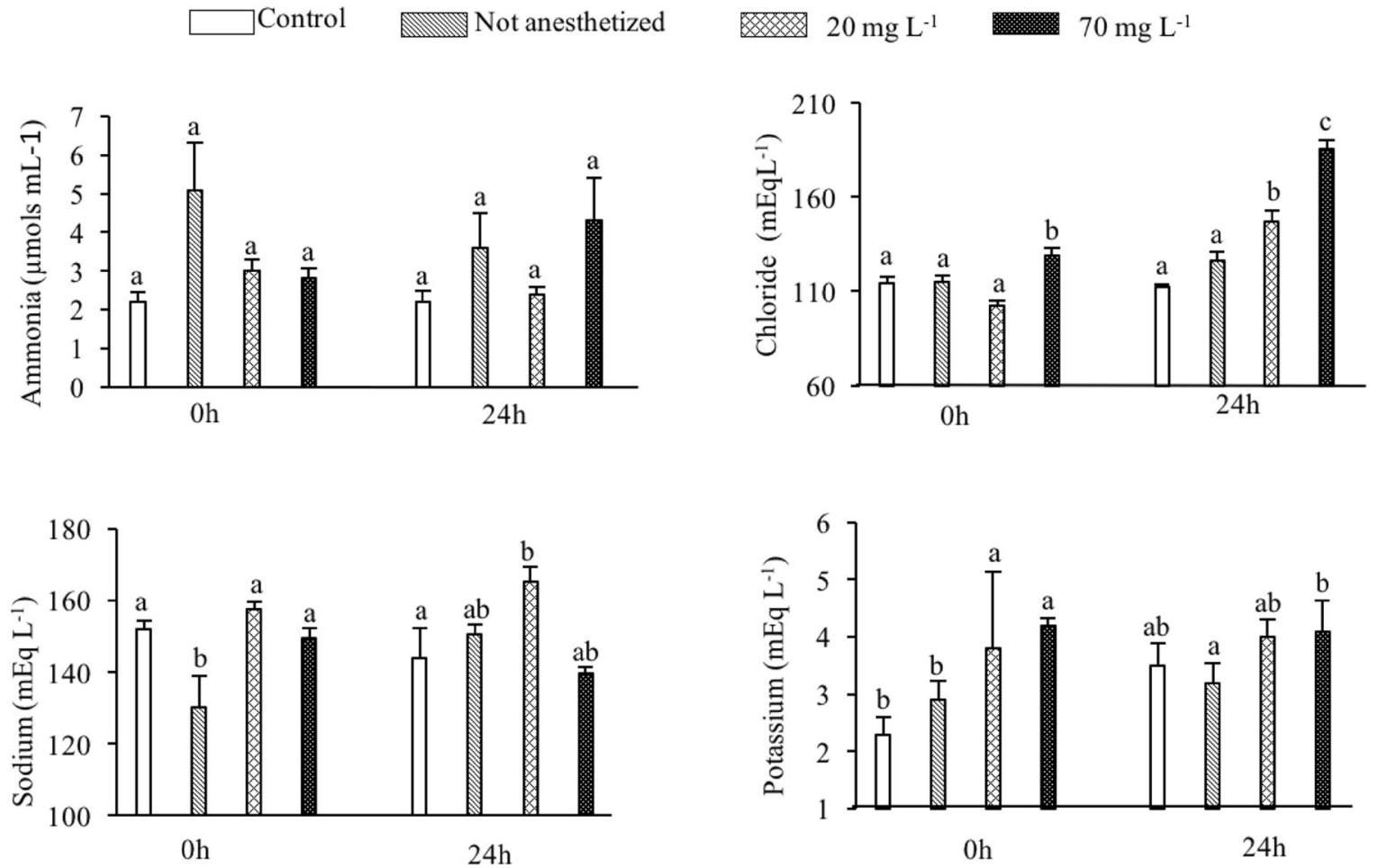

Fig. 4 Plasma ions of pacu subjected to anesthesia with essential oil Lippia sidoides. Plasma samples were taken 0 and $24 \mathrm{~h}$ after the experimental procedures. Control—neither submitted to handling nor anesthetic. Values are means \pm standard error $(N=9)$, and different lowercase letters indicate significant differences between treatments within the same sampling time $(0 \mathrm{~h}$ or $24 \mathrm{~h})$, using ANOVA one-way and Tukey's test $(P<0.05)$

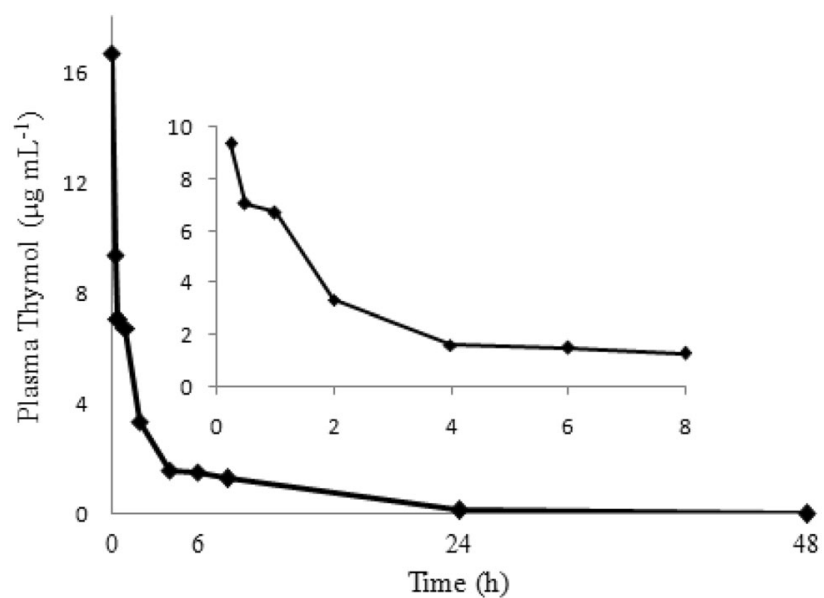

Fig. 5 Plasma concentrations of thymol in Piaractus mesopotamicus after an experimental anesthetic bath $(n=30)$. Blood samples were taken at 0,15 and $30 \mathrm{~min}, 1,2,4,6,8,24$ and $48 \mathrm{~h}$ after a $10 \mathrm{~min}$-exposure. Lippia sidoides essential oil was the test anesthetic in concentration of $70 \mathrm{mg} \mathrm{L}^{-1}$. Calculated thymol concentration in the anesthetic bath was $43 \mathrm{mg} \mathrm{L}^{-1}$

et al. 2014). However, several factors can influence the composition of essential oils, such as luminosity, temperature, pluviosity, plant nutrition, season, and sampling time, as well as harvesting and post-harvesting methods (Morais 2009). Nevertheless, the most important factor is the chemotype of the plant (Silva et al. 2013). An example is the essential oil of L. sidoides chemotype thymol, which has a concentration of $61.12 \%$ in this study. In other works with the same plant, the concentrations were 76.60\% (Hashimoto et al. 2016), 84.9\% (Veras et al. 2014), and 68.40\% (Silva et al. 2013). 
Table 2 Pharmacokinetic parameters of thymol in pacu after 10 min-anesthetic bath

\begin{tabular}{lr}
\hline Parameters & Values \\
\hline$C_{\text {Máx }}\left(\mu \mathrm{g} \mathrm{mL}^{-1}\right)$ & 16.67 \\
$K_{\text {dist }}\left(\mu \mathrm{g} \mathrm{mL}^{-1}\right)$ & 7.59 \\
$K_{\mathrm{el}}\left(\mu \mathrm{g} \mathrm{mL}^{-1}\right)$ & 0.44 \\
$T_{1 / 2 \alpha}(\mathrm{h})$ & 1.59 \\
$T_{1 / 2 \beta}(\mathrm{h})$ & 0.09 \\
AUC 0-last & 38.05 \\
\hline
\end{tabular}

Lippia sidoides was the test anesthetic in concentration of $70 \mathrm{mg} \mathrm{L}^{-1}$. Calculated thymol concentration in the anesthetic bath was $43 \mathrm{mg} \mathrm{L}^{-1}$. Water temperature was $24^{\circ} \mathrm{C}$

The lowest $L$. sidoides essential oil concentration that induced anesthesia in this work was $20 \mathrm{mg} \mathrm{L}^{-1}$. Two chemotypes of $L$. sidoides were reported by Silva et al. (2013), thymol $68.4 \%$ and carvacrol $67.89 \%$. The similar fish anesthetic effects observed for both chemotypes may be associated with the synergistic interactions among the constituents, as described for other plants by Spinella (2002) and Heldwein et al. (2014). Regarding L. sidoides actions on the central nervous system (CNS) in this study, thymol can be singled out. This substance was described as a positive allosteric modulator of GABA (gamma-aminobutyric acid) receptors in cockroaches and flies (Tong and Coats 2010). The GABA receptors correspond to the main targets for anesthetic actions when these substances are evaluated for animals (Johnston et al. 2006). The studied concentrations of $L$. sidoides essential oil with the considered exposure time $(10 \mathrm{~min})$ are safe as a fish anesthetic. Experimental animals displayed recovery after the anesthetic procedures with $100 \%$ survival, even after 20 days.

Hematological indexes were closely related to the animal's response to environmental variables imposed by either natural or artificial stimuli, such as farming practices (Fernandes and Mason 2003). Alterations in erythrocyte parameters can be attributed to hemoconcentration, caused by increased oxygen demands during recovery to handle the anesthesia (Morales et al. 2005). Similar results in blood parameters were reported by Soares et al. (2016) and Soares et al. (2017), who evaluated the physiological effects of L. alba and L. sidoides in tambaqui.

Plasma glucose is one of the most used physiological stress indicators in fish, especially in field studies (Hattingh 1976). Increases in some blood parameters occur immediately after the nervous system receives one or more adverse stimuli, activating two metabolic axes, the CPI (cerebrum-pituitary-interrenal cells) and the CSC (cerebrum, sympathetic chromaffin cells). Cortisol and catecholamine are released into the bloodstream initiating metabolic processes for extra energy production allowing fish to escape or adapt to the new condition (Iwama et al. 2004). The hyperglycemia observed in fish exposed to 20 and $70 \mathrm{mg} \mathrm{L}^{-1}$ of the L. sidoides essential oil at time zero and the glucose decrease, but not to control values, $24 \mathrm{~h}$ after the experimental anesthesia procedures, agrees with studies performed with $L$. alba essential oil in tambaqui (Soares et al. 2016) and tilapia (O. niloticus) (Hashimoto et al. 2016).

The increased plasma lactate was caused by a greater energy demand than aerobic metabolism can supply. In addition, some stressors as unfamiliar substances dissolved in the water may also impair oxygen absorption through the gills (Soares et al. 2016). Thus, in both conditions, anaerobic metabolism increases, and more lactate is released into the blood. These are the common situations in stress because fish are not capable of sustaining the physiological energy needs (Iwama et al. 2004). Similar results were observed when using the essential oil of $O$. gratissimum as an anesthetic for matrinxã (Ribeiro et al. 2016) and when evaluating metabolic responses of tambaqui anesthetized with eugenol (Inoue et al. 2011). However, when anesthetizing tambaqui with the essential oil of $O$. gratissimum, no alterations were observed in lactate serum levels (Boijink et al. 2016).

An increase in the plasmatic ammonia of fish is considered a stress indicator of altered protein metabolism and/or impairments in the nitrogen excretion through the gills (Inoue et al. 2011). In this work, the experimental procedures were not stressful enough in Piaractus mesopotamicus to trigger the physiological responses concerned with nitrogen metabolism and excretion. In tambaqui anesthetized with eugenol (Inoue 
et al. 2011), an increase in plasma ammonia was observed in response to handling and also to anesthetic baths at concentrations of 20 and $60 \mathrm{mg} \mathrm{L}^{-1}$ eugenol.

Increases in plasma ammonia were also observed in anesthetized tambaqui with essential oil of $O$. gratissimum (Boijink et al. 2016). Fish in stress have altered frequencies of opercular movements. Water fluxes and exchanges in the gills are consequently affected (Summerfelt and Smith 1990). Juvenile tambaqui anesthetized with the essential oil of $O$. gratissimum had no ion alterations (Boijink et al. 2016), but in a study with the same fish species anesthetized with menthol, higher potassium plasmatic levels were observed (Façanha and Gomes 2005). Thus, fish suffer reductions in both nervous and respiratory functions, causing the alteration in blood flow, hampering ion exchanges because of the anesthetic (Summerfelt and Smith 1990). Fish in deep anesthesia may not be able to adequately transport metabolites. However, based on the results of this study, it was not possible to affirm that the alterations in plasmatic ions were exclusively caused by the use of the essential oil.

The pharmacokinetics of the essential oil of L. sidoides on the plasma of Piaractus mesopotamicus was described by the open model of two compartments with elimination of the first order. Benzocaine had a similar response in salmon and trout (Stehly et al. 1998; Kiessling et al. 2009). The biphasic elimination curve of thymol in this work suggests enterohepatic circulation, which is common in phenolic compounds, subjected to conjuration (Marier et al. 2002). This process may contribute to an increased time to eliminate the compound. Thymol chemical attributes, such as relatively low molecular weight and high lipid solubility, favored branchial absorption. Anesthetics may also be absorbed via epithelium (Ferreira et al. 1984). However, a rapid absorption was unlikely because of the slightly small vascular space in dermic layers limits the number of compounds that may quickly reach the bloodstream (Ferreira et al. 1984). The major compound of $L$. sidoides, thymol, was rapidly distributed and eliminated from blood plasma in the first $2 \mathrm{~h}$ after the immersion bath.

Gill elimination has been shown to be the most important depuration mechanism for anesthetics, including benzocaine, MS222, and isoeugenol in salmon (Kiessling et al. 2009). In addition, excretion metabolism enables elimination of combined substances through urinary and biliary routes (Noga 2010). The elimination constants were determined by factors such as water quality (Hiney et al. 1995). Thymol was rapidly eliminated at $24{ }^{\circ} \mathrm{C}$ in this study; there was a $64.31 \%$ reduction in the first hour, and the elimination half-life $\left(T_{1 / 2} \beta\right)$ was $1.59 \mathrm{~h}$. By way of comparison, other fish anesthetics, such as benzocaine and eugenol, had half-lives higher than $12 \mathrm{~h}$ in trout (Meinertz et al. 1996; Stehly et al. 1998; Guénette et al. 2007). However, there are no studies of fish anesthetic clearance at temperatures higher than $12{ }^{\circ} \mathrm{C}$.

In conclusion, the essential oil of $L$. sidoides presented efficacy as an anesthetic for $P$. mesopotamicus. It was considered safe with $100 \%$ fish survival even after 20 days. Additionally, the results support the development of other studies testing natural anesthetics or even with L. sidoides essential oil in other fish species and with other protocols. Information regarding the plasma and muscle deposition paths based on $L$. sidoides essential oil for fish was provided.

Acknowledgements The authors are grateful to Conselho Nacional de Desenvolvimento Cientifico e Tecnológico (CNPQ 471655/10-4 and CNPq Proc. 310801/2015-0), Empresa Brasileira de Pesquisa Agropecuária (EMBRAPA 02.12.01.020.00.03 and 03.17.00.051.00.01.005). This study was financed in part by the Coordenação de Aperfeiçoamento de Pessoal de Nível Superior - Brasil (CAPES) - Finance Code 001 and Fundação de Apoio ao Desenvolvimento do Ensino, Ciência e Tecnologia do Estado de Mato Grosso do Sul (FUNDECT -126/2016, SIAFEM 025886).

\section{Compliance with ethical standards}

Conflict of interest The authors declare that they have no conflict of interest.

Open Access This article is distributed under the terms of the Creative Commons Attribution 4.0 International License (http:// creativecommons.org/licenses/by/4.0/), which permits unrestricted use, distribution, and reproduction in any medium, provided you give appropriate credit to the original author(s) and the source, provide a link to the Creative Commons license, and indicate if changes were made.

\section{References}

Adams RP (2007) Identification of essential oil components by gas chromatography/ mass spectroscopy, 1st edn. Allured Publishing Corporation, Carol Stream 
Boijink C, Queiroz C, Chagas E, Chaves F, Inoue L (2016) Anaesthetic and anthelminthic effects of clove basil (Ocimum gratissimum) essential oil for tambaqui. Aquaculture 457:24-28. https://doi.org/10.1016/j.aquaculture.2016.02.010

Cavalcanti S, Nicolau E, Blank A, Câmara C, Araújo I, Alves P (2010) Composition and acaricidal activity of Lippia sidoides essential oil against two-spotted spider mite (Tetranychus urticae Koch). Bioresour Techol 101:829-832. https://doi.org/10. 1016/j.biortech.2009.08.053

Cunha M, Barros F, Garcia L, Veeck A, Heinzmann B, Loro V, Emanuelli T, Baldisserotto B (2010) Essential oil of Lippia alba: a new anesthetic for silver catfish. Aquaculture 306:403-406. https://doi.org/10.1016/j.aquaculture.2010.06.014

Cunha M, Silva B, Delunardo F, Benovit S, Gomes L, Heinzmann B, Baldisserotto B (2011) Anesthetic induction and recovery of Hippocampus reidi exposed to the essential oil of Lippia alba. Neotrop Ichthyol 9:683-688. https://doi.org/10.1590/S167962252011000300022

Drabkin D (1948) The standardization of hemoglobin measurement. Am J Med Sci 215:110-111

Façanha M, Gomes L (2005) Efficacy of menthol as an anesthetic for tambaqui (Colossoma macropomum). Acta Amazon 35:71-75. https://doi.org/10.1590/S0044-59672005000100011

Fernandes M, Mason A (2003) Environmental pollution and fish gill morphology. In: Val A, Kapoor B (eds) Fish adaptations. Scientific Publishers, Enfield, New York, pp 203-231

Ferreira J, Schoonbee H, Smith G (1984) The uptake of the anaesthetic benzocaine hydrochloride by the gills and the skin of three freshwater fish species. J Fish Biol 25:35-41. https://doi.org/https://doi.org/10.1111/j.1095-8649.1984.tb04848.x.

Gentzkow C, Mazen J (1942) An accurate method for the determination of blood urea nitrogen by direct nesslerization. J Biol Chem 143:531-544

Guénette S, Uhland F, Hélie P, Beaudry F, Vachon P (2007) Pharmacokinetics of eugenol in rainbow trout. Aquaculture 266:262-265. https://doi.org/10.1016/j.aquaculture.2007.02.046

Hajek G (2011) The anaesthetic-like effect of tea tree oil in common carp Cyprinus carpio. Aquac Res 42:296-300. https://doi.org/ 10.1111/j.1365-2109.2010.02625.x.

Hashimoto G, Neto F, Ruiz M, Acchile M, Chagas E, Chaves F, Martins M (2016) Essential oils of Lippia sidoides and Mentha piperita against monogenean parasites and their influence on the hematology of Nile tilapia. Aquaculture 450:182-186. https://doi.org/10.1016/j.aquaculture.2015.07.029

Hattingh J (1976) Blood sugar as an indicator of stress in the freshwater Labeo capensis. J Fish Biol 10:191-195

Heldwein C, Silva L, Gai E, Roman C, Parodi T, Burger M, Baldisserotto B, Flores E, Heinzmann B (2014) Linalool from Lippia alba: sedative and anesthetic for silver catfish (Rhamdia quelen). Vet Anaesth Analg 41:621-629. https://doi.org/10.1111/ vaa.12146

Hiney M, Coyne R, Kerry J, Pursell L, Samuelsen O, Smith P (1995) Failure of flumisol bath treatments during commercial transport of Atlantic salmon smolts to prevent the activation of stress inducible furunculosis. Aquaculture 136:31-42. https:// doi.org/10.1016/0044-8486(95)01046-7

Inoue L, Santos-Neto C, Moraes G (2003) Clove oil as anesthesic for juveniles of matrinxã Brycon cephalus. Ciênc Rural 33:943-947. https://doi.org/10.1590/S0103-84782003000500023

Inoue L, Boijink C, Ribeiro P, Silva A, Affonso E (2011) Avaliação de respostas metabólicas do tambaqui exposto ao eugenol em banhos anestésicos. Acta Amazon 41:327-332

Iwama G, Afonso L, Todgham A, Ackerman P, Nakano N (2004) Are HSPS suitable for indicating stressed states in fish? J Exp Biol 204:15-19

Jambhekar S, Breen P (2009) Basic pharmacokinetics. Pharmaceutical Press, London

Johnston G, Hanrahan J, Chebib M, Duke R, Mewett K (2006) Modulation of ionotropic GABA receptors by natural products of plant origin. Adv Pharmacol 54:285-316

Kiessling A, Johansson D, Zahl I, Samuelsen O (2009) Pharmacokinetics, plasma cortisol and effective ness of benzocaine, MS222 and isoeugenol measured in individual dorsal aorta-cannulated Atlantic salmon (Salmo salar) following bath administration. Aquaculture 286:301-308. https://doi.org/10.1016/j.aquaculture.2008.09.037

Marier J, Vachon P, Gritsas A, Zhang J, Moreau J, Ducharme M (2002) Metabolism and disposition of resveratrol in rats: extent of absorption, glucuronidation, and enterohepatic recirculation evidenced by a linked-rat model. J Pharmacol Exp Ther 302:369-373

Medeiros M, Silva A, Citó A, Borges A, Lima S, Lopes J, Figueiredo R (2011) In vitro antileishmanial activity and cytotoxicity of essential oil from Lippia sidoides. Parasitol Int 60:237-241. https://doi.org/10.1016/j.parint.2011.03.004

Meinertz J, Stehly G, Gingerich W (1996) Pharmacokinetics of benzocaine in rainbow trout (Oncorhynchus mykiss) after intraarterial dosing. Aquaculture 148:39-48. https://doi.org/10.1016/S0044-8486(96)01406-8

Monteiro M, Leite A, Bertini L, Morais S, Pinheiro D (2007) Topical anti-inflammatory, gastroprotective and antioxidant effects of the essential oil of Lippia sidoides. J Ethnopharmacol 111:378-382. https://doi.org/10.1016/j.jep.2006.11.036.

Morais L (2009) Influência dos fatores abióticos na composição química dos óleos essenciais. Hortic Bras 27:4050-4063

Morales A, Cardenete G, Abellán E, García-Rejón L (2005) Stress-related physiological responses to handling in common dentex (Dentex dentex Linnaeus, 1758). Aquac Res 36:33-40. https://doi.org/10.1111/j.1365-2109.2004.01180.x

Noga E (2010) Fish disease: diagnoses and treatment, 2nd edn. Kindle Edition, New Jersey

Oliveira V, Moura D, Lopes J, Andrade P, Silva N, Figueiredo R (2009) Effects of essential oils from Cymbopogon citratus (DC) Stapf., Lippia sidoides Cham., and Ocimum gratissimum L. on growth and ultrastructure of Leishmania chagasi promastigotes. Parasitol Res 104:1053-1059. https://doi.org/10.1007/s00436-008-1288-6

Pharmacopoeia European (2007) European pharmacopoeia, 6th edn. European directorate for the quality of medicines, Strasbourg, France

Ranzani-Paiva M, Pádua S, Tavares-Dias M, Egami M (2013) Métodos para Análise Hematológica em Peixes, 1st edn. EDUEM, Maringá 
Ribeiro A, Batista E, Dairiki J, Chaves F, Inoue L (2016) Anesthetic properties of Ocimum gratissimum essential oil for juvenile matrinxã. Acta Sci Anim Sci 38:1-7. https://doi.org/10.4025/actascianimsci.v38i1.28787

Silva L, Silva D, Garlet Q, Cunha M, Mallmann C, Baldisserotto B, Longhi S, Pereira A, Heinzmann B (2013) Anesthetic activity of Brazilian native plants in silver catfish. Neotrop Ichthyol 11:443-451. https://doi.org/10.1590/S1679-62252013000200014

Silva L, Garlet Q, Koakoski G, Oliveira T, Barcellos L, Baldisserotto B, Pereira A, Heinzmann B (2015) Effects of anesthesia with the essential oil of Ocimum gratissimum L. in parameters of fish stress. Rev Bras Plantas Med 17:215-223. https://doi. org/10.1590/1983-084X/13_034

Silva L, Parodi T, Rekcziegel P, Garcia V, Burger M, Baldisserotto B, Mallmann C, Pereira A, Heinzmann B (2012) Essential oil of Ocimum gratissimum L.: anesthetic effects, mechanism faction and tolerance in silver catfish, Rhamdia quelen. Aquaculture 350:91-97. https://doi.org/10.1016/j.aquaculture.2012.04.012

Soares B, Neves L, Oliveira M, Chaves F, Chagas E, Tavares-Dias M (2016) Antiparasitic activity of the essential oil of Lippia alba on ectoparasites of Colossoma macropomum (tambaqui) and its physiological and histopathological effects. Aquaculture 452:107-114. https://doi.org/10.1016/j.aquaculture.2015.10.029

Soares B, Neves L, Ferreira D, Oliveira M, Chaves F, Chagas E, Gonçalves R, Tavares-Dias M (2017) Antiparasitic activity, histopathology and physiology of Colossoma macropomum (tambaqui) exposed to the essential oil of Lippia sidoides (Verbenaceae). Vet Parasitol 234:49-56. https://doi.org/10.1016/j.vetpar.2016.12.012

Spinella M (2002) The importance of pharmacological synergy in psychoactive herbal medicines. Altern Med Rev 7:130-137

Stehly G, Meinertz J, Gingerich W (1998) Effect of temperature on the pharmacokinetics of benzocaine in rainbow trout (Oncorhynchus mykiss) after bath exposures. J Vet Pharmacol Ther 21:121-127

Summerfelt R, Smith L (1990) Anesthesia, surgery, and related techniques. In: Schreck C, Moyle P (eds) Methods for fish biology. American Fisheries Society, Bethesda, pp 213-272

Tong F, Coats J (2010) Effects of monoterpenoid insecticides on [3H]-TBOB binding in house fly GABA receptor and 36Cl uptake in American cockroach ventral nerve cord. Pestic Biochem Physiol 98:317-324

Veras H, Rodrigues F, Botelho M, Menezes I, Coutinho H, Costa L (2014) Antimicrobial Effect of Lippia sidoides and thymol on Enterococcus faecalis biofilm of the bacterium isolated from Root Canals. Sci W J. https://doi.org/10.1155/2014/471580

Woody CA, Nelson J, Ramstad K (2002) Clove oil as an anaesthetic for adult sockeye salmon: field trails. J Fish Biol 60:340-347

Zahl IH, Samuelsen O, Kiessling A (2012) Anaesthesia of farmed fish: implications for welfare. Fish Physiol Biochem 38:201218. https://doi.org/10.1007/s10695-011-9565-1.

\section{Publisher's Note}

Springer Nature remains neutral with regard to jurisdictional claims in published maps and institutional affiliations. 